\title{
Role of Microbial Biofertilizers in Vegetable Production- A Review
}

\author{
Gurpreet Singh and Anamika Verma** \\ Department of Horticulture, School of Agriculture, Lovely Professional University, \\ Phagwara, Punjab, India \\ *Corresponding author
}

\section{A B S T R A C T}

Keywords

Azotobacter,

Biofertilizers,

Nitrogen fixing

biofertilizers, PSB,

Vegetables

Article Info

Accepted:

12 October 2020

Available Online:

10 November 2020
Biofertilizers comprises living microorganisms symbiotically associated with plants, when applied to soil or a propagule intends to increase the soil fertility, seed germination and plant growth by encouraging the efficient supply of nutrients to the plants. Since past 50-60 years, soil management practices are mostly reliant on inorganic fertilizers, which has invited serious fortune to the environment (ruining soil fertility and increased pollution) and human health problems (disease risk). Heeding to it researchers have found an eco-friendly alternative by the way of incorporating microbial biofertilizers to supersede chemical fertilizers. Microbial biofertilizers has been analysed as substitute in procuring soil fertility and expanding vegetable production. Microbial fertilizers are promising enough to outstand the chemical fertilizers ensuring sustainable agriculture without disrupting the environment.

\section{Introduction}

Biofertilizer term refers to substances containing effective strains of living microorganisms such as fungi, algae, bacteria that can expedite soil microbial activities to enhance the active supply of nutrients in a way that plants can easily incorporate. Inorganic fertilizers indeed played a significant role in enhancing agricultural productivity, but they overstretched the use of renewable sources. Although, farmers are still applying over dosage of chemical fertilizers in lieu of high production nevertheless their excess has cost us soil contamination, soil toxicity, water table contamination etc. causing environmental pollution (Mahdi et $a l ., 2010)$ as well as causing several types of cancers and cardiovascular disease in humans (Engel et al., 2000). Their quick action or contribution towards high yield and low price had brought them promptly into the prime focus of the marginal farmers. Among agricultural crops, vegetable crops being short-duration, flexible provided with high productivity accompanying health benefits plays a significant role in food trade especially in India. Vegetables are important for human nutrition in terms of bioactive nutrient molecules such as dietary fibre, 
vitamins and minerals, and non-nutritive phytochemicals (phenolic compounds, flavonoids, bioactive peptides, etc.). They are packed with vitamins $(\mathrm{C}, \mathrm{A}, \mathrm{B} 1, \mathrm{~B} 6, \mathrm{~B} 9, \mathrm{E})$ and anti-oxidants which can help in growth, repairing of body cells and reduce risk of dreadful diseases like cancers. These nutrient and non-nutrient molecules reduce the risk of chronic diseases such as cardiovascular diseases, diabetes, certain cancers, and obesity (Pennington et al., 2009; Malaterreb et al., 2018).

A high vegetable diet has been associated with reduced risk of human cardiovascular disease (Mullie and Clarys, 2011). Owing to health benefits and high productivity, area under vegetable production is constantly rising, and so is the chemical fertilizers application. Marginal farmers need to improvise their farming skills and incorporate organic farming or at least organic fertilizers and microbial biofertilizers. Organic farming contributes to quality vegetables therefore adoption and application of the microbial biofertilizer is mandatory for modern agriculture to flourish sustainably.

Biofertilizers are the essential component of organic farming as they help in maintaining soil fertility for longer time period. The microbes present in these fertilizers provide nutrient to plants by using different mechanism and also encourage immunity of plants to protect their selves from the attack of diseases and pests as well as abiotic stresses. Biofertilizers add nutrients through the natural processes of nitrogen fixation, solubilizing phosphorus and stimulating plant growth through the synthesis of growth promoting substances. Some biofertilizers are viz. symbiotic nitrogen fixing biofertilizers, free-living biofertilizers, associative symbiotic nitrogen fixing biofertilizers etc. Biofertilizers can be applied directly to the crop or also with the combination of chemical fertilizers and have different mode of action. If the microbial inoculant is not applied properly, the benefits from the biofertilizer may not be obtained. The biofertilizer can be synthesized in solid or in liquid form for spraying on the plants. Bio-fertilizers are usually amended with carrier material to increase effectiveness of the bio-fertilizers and also enhance the water retention capacity.

The incorporation of microorganisms into carrier materials enables easy handling, long term storage, and effectiveness of the biofertilizer. Carrier material such as saw dust, talcum dust, manure, earthworm cast can be used. There is lot of work done by many researchers to know the effects of biofertilizers and they have achieved many successful results. Keeping in mind the above key points, narrating the potential key role biological fertilizers could play if incorporated towards vegetable productivity and sustainable agriculture, we are presenting hereby a review of all researches done in this field exaggerating the fact how microbial biofertilzers could help in safeguarding the environment and prove as an eco-friendly and cost effective input for the farmers.

\section{Nitrogen fixing microbes}

Nitrogen fixing microbes comprises of symbiotic nitrogen fixing biofertilizers (including Rhizobium, Azolla etc.), free living nitrogen fixing biofertilizers [Azotobacter, Cyanobacteria (blue green algae) etc.] and associative symbiotic nitrogen fixing biofertilizers (Azospirillum). Along with these there are microbes which fix phosphorus or solubilize the phosphorus like Phosphorus Solubilizing Bacteria (PSB). Various studies done regarding the application of microbial fertilizers among vegetables and their beneficial effect towards yield and quality parameters have been provided in Table 1. 


\section{Symbiotic nitrogen fixing biofertilizers}

\section{Rhizobium}

These are the widely recognized symbiotic nitrogen fixers that belong to the Rhizobiaceae family and typically consist of various genera, such as Mesorhizobium, Sinorhizobium, Allorhizobium, Azorhizobium, Bradyrhizobium, and Rhizobium. Rhizobium are motile, gram-negative, non-sporulating rod type which tend to symbiotically fix atmospheric nitrogen. Rhizobium helps reduce the molecular $\mathrm{N} 2$ to $\mathrm{NH} 3$ in the root nodules, which is then readily absorbed by the plant roots.

The N-fixation is carried out by a complex enzyme nitogenase consisting of dinitrogenase reductase with iron as its cofactor and dintrogenase with molybdenum and iron as its cofactor (Mahanty et al., 2016).Rhizobium can fix 50-200 $\mathrm{kg} \mathrm{N}^{-1}$ which helps to meet up to 80 to $90 \%$ nitrogen need of the crop as their natural presence in nodulating legume crops makes them less dependent on inorganic nitrogen (Kour et al., 2020).

\section{Azolla}

It is a symbiotic diazotroph which has the capacity to fix nitrogen in the atmosphere found in temperate and tropical environments. There is a symbiotic relationship between Azolla and Anabaena cynobacteria. Azolla helps to provide the anabaena with a carbon source and its nitrogen requirement is met by cyanobacteria's atmospheric nitrogen fixation. The benefit of growing Azolla as a biofertilizer helps provide $\mathrm{N}$ and $\mathrm{K}$ requirements to the plant. Anabaena azollae is considered to be the most dominant biofertilizers and commonly used for the wetland rice in South-east Asia and estimated to fix around 40-60 Kg N/ha in rice crop (Kannaiyan, 1993).

\section{Free living nitrogen fixing biofertilizers}

\section{Azotobacter}

Azotobacters are free living nitrogen fixing bacteria which belongs to azotobacteriaceae family and mostly found in alkaline and neutral soils. It does not require any host and fixes the atmospheric nitrogen especially in non-leguminous plants without any symbiotic relationship (Jaga and Singh, 2010). Application of Azotobacteras bio-inoculants may increase $10-12 \%$ crop productivity leading to synthesis of ample amount of biologically active substance like nicotinic acid, biotin, heteroauxins, vitamin $\mathrm{B}$ and gibberellins etc, which increase root growth and uptake of the minerals (Jaga and Singh, 2010). Azotobacter sp. has the ability to produce antifungal antibiotics and fungi static compounds against pathogens like Fusarium sp., Alternaria sp., Trichodermasp etc.

\section{Cyanobacteria}

Cyanobacteria referred as "blue-green algae" or BGA, are free living, aquatic, small, unicellular bacteria and possess photosynthetic property i.e. they can manufacture their own food. They are one of the largest bacterial species and the dominant nitrogen fixers among them are Calothrix, Nostoc, Anabaena and Aulosira (Sahu et al., 2012). By building up soil fertility, they help to increase yield along with excretion of various substances that promote growth, e.g. amino acids, phytohormones, vitamins (Rodríguez et al., 2006), soil salinity reduction, weed growth prevention, soil $\mathrm{P}$ content increase (Wilson, 2006) etc. When inoculated with cyanobacteria, vegetables such as chilli, spinach, radish, tomato have shown the beneficial effects (Thajuddin and Subramanian, 2005). Nostoc and Anabaena are have been found to fix about $20-25 \mathrm{Kg}$ of $\mathrm{N} / \mathrm{ha}$ (Kour et al., 2020). 
Table.1 Application of microbial biofertilizers among various vegetables and their effects on growth and production

\begin{tabular}{|c|c|c|c|c|c|}
\hline $\begin{array}{l}\text { S. } \\
\text { no. }\end{array}$ & Biofertilizer & Plant & Description & $\begin{array}{l}\text { Inorganic } \\
\text { fertilizer used }\end{array}$ & References \\
\hline 1. & PSB & Asparagus & $\begin{array}{l}\text { All growth characters in asparagus were maximum when PSB } \\
\text { was applied with organic fertilizers. }\end{array}$ & Applied & Palande et al., (2017) \\
\hline 2. & Azotobacter, PSB & Bottlegourd & $\begin{array}{l}\text { Application of } 2.5 \mathrm{~kg} \text { dose of Azotobacter and PSB each found } \\
\text { highly profitable resulting high C:B ratio. }\end{array}$ & Applied & Patle et al., (2018) \\
\hline 3. & $\begin{array}{l}\text { Azospirillum, } \\
\text { Phosphobacteria }\end{array}$ & Brinjal & $\begin{array}{l}\text { Combined application of microbial fertilizers and chemical } \\
\text { fertilizers enhanced growth and yield. }\end{array}$ & Applied & Latha et al., (2014) \\
\hline 4. & $\begin{array}{l}\text { Azotobacter, } \\
\text { Azospirillum, PSB }\end{array}$ & Brinjal & $\begin{array}{l}\text { Growth and yield attributes increased with } \\
\text { Azotobacter }+ \text { Azospirillum+PSB application. }\end{array}$ & Applied & Solanki et al., (2010) \\
\hline 5. & Azotobacterand PSB & Brinjal & $\begin{array}{l}\text { Morphological and yield characters of the plant were maximum } \\
\text { by the application of Azotobacter and PSB alone provided with } \\
\text { biotic stress resistance. }\end{array}$ & Applied & Doifode et al., (2014) \\
\hline 6. & Azospirillum, PSB & Brinjal & $\begin{array}{l}\text { Growth and yield components were maximum with root diping } \\
\text { treatment of } 125 \mathrm{~g} \text { Azospirillum and PSB. }\end{array}$ & Applied & Kiran (2006) \\
\hline 7. & $\begin{array}{l}\text { Azospirillum, PSB, } \\
\text { VAM, Azotobacter }\end{array}$ & Broccoli & $\begin{array}{l}\text { Curd size, yield, protein, lipid, sulphate contents of broccoli } \\
\text { curd was maximized after applying } 50 \% \text { Azospirillum and } \\
\text { Azotobacter. }\end{array}$ & Applied & Singh et al., (2014) \\
\hline 8. & $\begin{array}{l}\text { Azotobacter, } \\
\text { Azospirillum }\end{array}$ & Cabbage & $\begin{array}{l}\text { Azotobacter and Azospirillum were used as the organic source } \\
\text { of nitrogen. }\end{array}$ & Applied & Gupta et al., (2004) \\
\hline 9. & Azospirillum & Carrot & $\begin{array}{l}\text { Morpho-physiological, yield, biochemical components } \\
\text { increased with Azospirillum application. }\end{array}$ & Applied & Mog,B. (2007) \\
\hline 10. & $\begin{array}{l}\text { Azospirillum, } \\
\text { PSB,VAM, } \\
\text { Azotobacter }\end{array}$ & Cauliflower & $\begin{array}{l}\text { The application of Azotobacter, Azospirillum, VAM and PSB } \\
\text { significantly increased growth parameters when PSB was } \\
\text { followed by Azospirillum.VAM followed by PSB gave better } \\
\text { leaf width. PSB significantly increased curd size and curd } \\
\text { weight. }\end{array}$ & Applied & Kachari et al., (2009) \\
\hline 11. & $\begin{array}{l}\text { Azotobacter and } \\
\text { Azospirillum }\end{array}$ & Chilli & $\begin{array}{l}\text { Azotobacter along with RDF gave the high yield. Azospirillum } \\
\text { treatment gave high growth parameters. Azospirillum was found } \\
\text { better over Azotobacter. }\end{array}$ & Applied & Khan \&Pariari (2012) \\
\hline 12. & PSB, Rhizobium & Frenchbean & $\begin{array}{l}\text { Pod yield/ha maximized with Rhizobium+ PSB+ Organic } \\
\text { matter. }\end{array}$ & Applied & Thakur et al., (2018) \\
\hline 13. & VAM and PSB & Frenchbean & $\begin{array}{l}\text { Growth and yield characters of French bean wereenhanced due } \\
\text { to application of } 2 \mathrm{~kg} \text { VAM and } 2.5 \mathrm{~kg} \text { PSB per ha. }\end{array}$ & Applied & Ramana et al., (2010) \\
\hline 14. & Rhizobium & French bean & $\begin{array}{l}\text { Seeds inoculated with synthetic Rhizobium gave the maximum } \\
\text { growth,yield and seed quality components. }\end{array}$ & Not applied & Ahmed et al., (2016) \\
\hline
\end{tabular}




\begin{tabular}{|c|c|c|c|c|c|}
\hline 15. & $\begin{array}{l}\text { Azospirillum, } \\
\text { Azotobacter, PSB }\end{array}$ & Knol-khol & $\begin{array}{l}\text { PSB, Azotobacter and Azospirillum inoculation lead to yield and } \\
\text { biochemical parameters. }\end{array}$ & Applied & Choudhary et al., (2017) \\
\hline 16. & $\begin{array}{l}\text { Azotobacter, } \\
\text { Azospirillum, } \\
\text { Pseudomonas }\end{array}$ & Lettuce & $\begin{array}{l}\text { Plant height, no. of leaves, leaf area index and yield was } \\
\text { maximum in seed inoculation with Azospirillum. }\end{array}$ & Not applied & $\begin{array}{l}\text { Chamangasht et al., } \\
\text { (2012) }\end{array}$ \\
\hline 17. & Azospirillum & Lettuce & $\begin{array}{l}\text { Azospirillum inoculated lettuce seeds yield a higher number of } \\
\text { transplanted plants with superior quality than non-inoculated } \\
\text { ones. }\end{array}$ & Not applied & Fasciglione et al., (2012) \\
\hline 18. & Azotobacter, PSB & Okra & $\begin{array}{l}\text { The highest yield parameters were obtained with the application } \\
\text { of combination of organic manures together with Azotobacter } \\
\text { and PSB in okra crop. }\end{array}$ & Applied & Bairwa et al., (2009) \\
\hline 19. & Azospirillum & Onion & $\begin{array}{l}\text { The application of Azospirillum, increased the yield of onion } \\
\text { and also enhanced the nitrogen level in soil. }\end{array}$ & Applied & Yadav et al., (2004) \\
\hline 20. & $\begin{array}{l}\text { Azospirillum, VAM, } \\
\text { PSB }\end{array}$ & Onion & $\begin{array}{l}\text { Seed yield of onion was maximum when treated with } \mathrm{GA}_{3} \text { along } \\
\text { with Azospirillum+PSB+VAM }\end{array}$ & Not applied & Waghmode et al., (2010) \\
\hline 21. & Microbein & Onion & $\begin{array}{l}\text { Highest yield of total bulbs and increase in } \mathrm{N}, \mathrm{P}, \mathrm{K}, \mathrm{Fe}, \mathrm{Mn}, \mathrm{Zn} \text {, } \\
\mathrm{Cu}, \mathrm{Pb}, \mathrm{NO} 3 \text { and } \mathrm{NH} 4 \text { was obtained. }\end{array}$ & $\begin{array}{l}\text { Organic manure } \\
\text { applied }\end{array}$ & Shaheen et al., (2007) \\
\hline 22. & Azotobacter, PSB & Potato & $\begin{array}{l}\text { Application of Azotobacter along with combination of PSB and } \\
\text { organic manure enhanced the high yield of potato. }\end{array}$ & $\begin{array}{l}\text { Organic manure } \\
\text { applied }\end{array}$ & Kumar et al., (2013) \\
\hline 23. & Azotobacter & Potato & $\begin{array}{l}\text { Azotobacter alongwith the } 75 \% \text { RDF of nitrogen and } \\
\text { phosphorus resulted in higher yield per hectare. }\end{array}$ & Applied & Kumar et al., (2006) \\
\hline 24. & Azotobacter & Potato & $\begin{array}{l}\text { Azotobacter increased the yield of tuber by } 4-24 \% \text { along with } \\
\text { nitrogen. }\end{array}$ & Applied & Singh,K.(2001) \\
\hline 25. & $\begin{array}{l}\text { Rhizobacterin, } \\
\text { MicrobeinandPhosph } \\
\text { orein }\end{array}$ & Potato & $\begin{array}{l}\text { Cultivar diamond gave the high yield when treated with } \\
\text { phosphorein whereas rhizobacterin treatment gave the highest } \\
\text { tuber weight. }\end{array}$ & Not applied & Farag et al. (2013) \\
\hline 26. & Nitroxin, $P S B$ & Pumpkin & $\begin{array}{l}\text { Application of biofertilizeralongwith } 50 \% \text { chemical fertilizers } \\
\text { gave the maximum seed yield, fruit yield, photosynthesis rate } \\
\text { and chlorophyll content. }\end{array}$ & Applied & Habibi et al., (2013) \\
\hline 27. & $\begin{array}{l}\text { Azospirillum, PSB, } \\
\text { Azotobacter }\end{array}$ & Radish & $\begin{array}{l}\text { Growth, yield, and nutritional quality of radish maximizedwhen } \\
\text { one fourth quantity of Azotobacter, Azospirillum, PSB } \\
\text { alongwith RDF were applied. }\end{array}$ & Applied & Shani et al., (2017) \\
\hline 28. & Azotobacter & Tomato & $\begin{array}{l}\text { Application of Azotobacter with RDF }(150 \mathrm{~kg} \mathrm{~N}+60 \mathrm{~kg} \mathrm{P}+60 \\
\mathrm{Kg} / \mathrm{ha}) \text { increased the growth and yield parameters of the plant. }\end{array}$ & Applied & Gabhiye et al., (2003) \\
\hline 29. & $\begin{array}{l}\text { Azotobactor, Azospiri } \\
\text { lium and } P S B\end{array}$ & Tomato & $\begin{array}{l}\text { Fruit yield maximized when treated with RDF + PSB whereas, } \\
\text { fruit quality increased with RDF+ azospirillum+PSB. }\end{array}$ & Applied & Kadlag et al., (2007) \\
\hline 30. & Nitrobin & Tomato & $\begin{array}{l}\text { Nitrobinbiofertilizer enhanced tomato growth and yield } \\
\text { characters. }\end{array}$ & Applied & Gmaa.(2015) \\
\hline
\end{tabular}


Associative symbiotic nitrogen fixing biofertilizers

\section{Azospirillum}

Azospirillum is a gram negative motile bacteria belonging to order Rhodospirillales, with currently 17 species in use as biofertilizers, Azospirillum brasilense and Azospirillum lipoferum are most widely used species (Rodrigues et al., 2015). It promotes plant growth enhancing IAA, gibberellins and cytokinins production and found to fix 20$40 \mathrm{~kg} / \mathrm{N} /$ year when applied in non-leguminous plants. They can easily be isolated from the soil and from the aerial part of the plant. Azospirillum's key effects consist of modifications in root morphology that eventually stimulates plant growth (FibachPaldi et al., 2011). It was determined that by triggering cell wall modifications and osmotic adjustments, it can assist in plant survival under stressful conditions (Groppa et al., 2012; Richardson et al., 2009). The strains of Azospirillum are widely applied as biofertilizers in various vegetables (Hungria et al., 2010; Mehnaz, 2015).

\section{Phosphorus Solubilizing Bacteria (PSB)}

Phosphorus is a major nutrient that plays a crucial role in fostering crop growth and development (Soetan et al., 2010). Its bioavailability is very poor and therefore not accessible to plants. It is available in two forms in the soil, i.e. organic and inorganic. Inorganic $\mathrm{P}$ is supplied in precipitated form by chemical fertilisers and plants cannot take up this form of Phosphorus. Phosphobacteria have the ability of converting the insoluble form of phosphorus to a soluble form and make it available to plant by releasing various organic acids (succinic acid, oxalic acid, glutamic acid, citric acid, malic acid and fumaric acid). Taking into account the exchange reaction, chelation and acidification these bacteria solubilizes the insoluble phosphorus for plants. From soil, different species of Pseudomonas and Bacillus have been isolated which exhibit the P-solubilising attributes (Mishra et al., 2014). PSB can applied in all vegetables through seed treatment, soil application or seedling dip. Plants with limited root systems would be the most benefitted by PSB application (Abd ElLattief, 2016).

\section{Vesicular Arbuscular Mycorrhiza (VAM)}

VAM fungi are inter-cellular and obligatory endosymbiotics that have a beneficial relationship with plant roots since it extends and contaminates within the root zone. The root system transports nutrients to fungi and instead fungi tend to sustain plant roots with water and nutrients. Root length can expand through fungal hyphae and hyphae extend around 100 times in soils and enables plants to accumulate several nutrients. VAM fungi improve seedling tolerance to high temperature, drought and insect pest attack.

\section{Factors limitating the use of biofertilizers}

Lack of awareness among farmers.

Biofertilizers are plant specific i.e. one biofertilizer which works on one crop does not helps in another crop.

They have short shelf-life as compared to chemical fertilizer so the major problem is storage for long term.

Unavailability of carrier material for specific biofertilizer.

Biofertilizers requirement is more to fulfil the need of nutrient required by the plant.

\section{Future prospects}

Realizing the importance of biofertilizers and their implementation in modern agriculture is a must. Biofertilizers helps in improving the productivity and the fertility of soil so more 
food will produce to feed burgeoning population. Biofertilizers will gradually help soil to regain its fertility for long term health. Biofertilizers application will reduce the use of chemical fertilizers and thus it reduces the additional cost of farmers. They are ecofriendly in nature and reduce the environmental pollution. Biofertilizers are only at the starting phase still need more efforts to bring changes in modern agriculture. Microbial extraction, their colonization, production, marketing, application, good knowledge among farmers etc. are necessary for more and more utilization of biofertilizers in modern agriculture aiming at the reduction of chemical fertilizer application in the field for high productivity. More studies in the field of plant and microbes interaction are required so that more efficient technology is used to get more production without disturbing the environment. Biofertilizers like Azotobacter, Azospirillium, Phosphobacter, Rhodobacter etc. can help plant to survive in stress conditions and to perform well. The application of biofertilizers not only will benefit the agricultural ecosystem but it also contributing to a holistic and sustainable environment.

In conclusion the modern agriculture, the excessive use of chemical fertilizers and pesticides is disturbing the sustainability of our agricultural land. These chemicals are becoming threat to human health because of consumption of chemically produced food by humans resulting dreadful diseases. These chemicals also have atrocious impacts on air, water and soil, thus disturbing the ecological balance. Use of biofertilizers is becoming a big challenge to ensure the food safety and environment protection. Now attention is shifting towards organic production of food because of the harmful effects of the chemical fertilizers. The application of bio-fertilizers having beneficial microbes is gaining importance in promoting the crop productivity to a large extent and can help to solve the food need problem of increasing population of world. Soil erosion, water logging, accumulation of toxic elements are the main reasons which diminished the soil fertility in India. Biofertilizers are helpful in solving such kinds of problems and make the soil more productive as they are eco-friendly in nature.

\section{References}

Abd El-Lattief EA.2016.Use of Azospirillum and Azobacter bacteria as biofertilizers in cereal crops: A review. Int. J. Appl.Eng.Res., 6(7): 36- 44.

Ahmed,I., Khan,M.A., Ahmed, N., Khan,N., Khan, S., Yazdan, F. and Marwat, S.2016. Influence of Rhizobium inoculation on nodules, growth and yield of French beans cultivars. Int. J. Biosci., 9(6):226-233.

Bairwa,H.L., Shukla, A.K., Mahawer, L.N., Kaushik, R.A., Shukla, K.B. and Ameta, K.D.2009. Response of integrated nutrient management on yield, quality and physico-chemical characteristics of okra cv. ArkaAnamika. Indian J. Hortic., 66(3):310-314.

Chamangasht, S., Ardakani, M. R., Khavazi, K., Abbaszadeh, B., and Mafakheri, S.2012. Improving lettuce (Lactuca sativa L.) growth and yield by the application of biofertilizers. Ann. Biol. Res., 3(4): 1876-1879.

Choudhary, M., Jat, R.K., Chand, P. and Choudhary, R. 2017. Effect of biofertilizers on growth, yield and quality of Knol-Khol. J. Pharmacogn. phytochem., 6(6): 2234-2237.

Doifode, V.D., and Nandkar, P.B. 2014. Influence of biofertilizers on the growth, yield and quality of brinjal crop. Int. J. Life Sci., 2:17-20.

Engel, L.S., O'Meara, E.S. and Schwartz, 
S.M.2000. Maternal occupation in agriculture and risk of limb defects in Washington State, 1980-1993.Scand. J.Work Environ. Health, 26:193-198.

Farag Jr, M.I., AlyAbdalla, M., Mohamed, M.F. and Aboul-Nasr, M.H.2013. Effect of Biofertilization on Yield and Quality of some Potato Cultivars (Solanum tuberosum L.). Int J. food Sci. Tech., 4(7): 695-702.

Fasciglione, G., Casanovas, E. M., Yommi, A., Sueldo, R. J. and Barassi, C. A. 2012. Azospirillum improves lettuce growth and transplant under saline conditions. J. Sci. Food Agric., 92(12): 2518-2523.

Fibach-Paldi, S., Burdman, S. and Okon, Y.2011.Key physiological properties contributing to rhizosphere adaptation and plant growth promotion abilities of Azospirillum brasilense. FEMS Microbiol. Lett., 326: 99-108.

Gabhiye, R.P., sharma,R.R. and Tewari R. N.2003.. Effect of biofertilizers on growth and yield parameters of tomato. Indian J. Hort., 60(4): 368-71.

Gmaa, S.S. 2015. Effect of organic and biofertilization on tomato production. Int.J.Adv.Res., 3(10):1799-1805.

Groppa, M.D., Benavides, M.P. and Zawoznik, M.S. 2012. Root hydraulic conductance, aquaporins and plant growth promoting microorganisms: a revision. Appl. Soil Ecol., 61:247-254.

Gupta, A.K. and Samnotra, R.K. 2004.Effects of biofertilizers and nitrogen on growth, quality and yield of cabbage (Brassica oleracea var. capitata) cv. Golden acre. Envir. Ecol., 22(3):551-53.

Habibi, A., Heidari, G. R., Sohrabi, Y. and Mohamadi, K. 2013. Effect of biofertilizers and chemical fertilizers on yield and yield components of pumpkin (Cucurbita pepo L. Convar. pepo Var. styriaca). Iranian J. Med. Arom. Plants, 28(4), 604-615.
Hungria, M., Campo, R.J., Souza, E.M. and Pedrosa, F.O.2010. Inoculation with selected strains of Azospirillum brasilense and A. lipoferum improves yields of maize and wheat in Brazil. Plant Soil., 331: 413-425.

Jaga, P. and Singh, V. 2010. Effect of biofertilizer, nitrogen and sulphur on sorghum-mustard cropping system. In: Proceedings of National Seminar on Soil Security for Sustainable Agriculture held at College of Agriculture,. Nagpur.

Kadlag, A.D., Jadhav, A.B. andRaina, B. 2007. Yield and quality of tomato fruit as influenced by biofertilizers. Asian J.Soil.Sci., 2(2): 95-99.

Kachari,M. andKorla,B.N.2009. Effect of biofertilizers on growth and yield of cauliflower cv. PSBK-1. Indian J. Hort., 66(4):496-501.

Kannaiyan, S. 1993. Nitrogen contribution by Azolla to rice crop. Proc. Indian Nat. Sci. Acad., 3: 309-314.

Khan, S. andPariari, A. 2012.Effect of NFixing Biofertilizers on growth, yield and quality of chilli (Capsicum annuum L.). The Bioscan., 7(3):481-482.

Kiran, J. 2006. Effect of fertilizer biofertilizer and micronutrients on seed yield and quality of brinjal (Solanum melongena L.) (Doctoral dissertation, UAS, Dharwad).

Kour, D., Rana, K.L., Yadav, A.N., Yadav, N., Kumar, M., Kumar, V. and Saxena, A.K. 2020. Microbial biofertilizers: Bioresources and eco-friendly technologies for agricultural and environmental sustainability. Biocatal. Agric. Biotechnol., 23:101487.

Kumar, M., Baishya, L. K., Ghosh, D.C., Ghosh, M., Gupta, V K. and Verma, M.R. 2013. Effects of organic manures, chemical fertilizers and biofertilizers on growth and productivity of rainfed potato in the eastern Himalayas. J. plant 
Nutr., 36(7): 1065-1082.

Kumar, V., Jaiswal, R.C., Verma, R.B. and Singh A.P. 2006. Production potential of biofrtilizers in potato (Solanum tuberosum L.). Prog. Hort., 38(1):10508 .

Latha, P., Jeyaraman, S. andPrabakaran, R. 2014. Study effects of microbial and chemical fertilizer on yield components in brinjal (Solanum melongena Linn.) C. var CO-2. Int J. Curr. Microbiol Appl. Sci., 3(8):817-822.

Mahanty, T., Bhattacharjee, S., Goswami, M., Bhattacharyya, P., Das, B., Ghosh, A. and Tribedi, P. 2017. Biofertilizers: a potential approach for sustainable agriculture development. Environ. Sci. Pollut. Res., 24(4):3315-3335.

Malaterreb, S.A., Remizeb, F. and Pouchereta, P. 2018. Fruits and vegetables, as a source of nutritional compounds and phytochemicals: Changes in bioactive compounds during lactic fermentation. Food Res. Int., 8699.

Mahdi, S.S., Hassan, G., Samoon, S., Rather, H., Dar, S.A. andZehra, B.2010.Biofertilizers in organic agriculture.J. Phytol., (2): 42-54.

Mehnaz, S. 2015. Azospirillum: a biofertilizer for every crop. In: Arora, N.K. (Ed.), Plant Microbes Symbiosis: Applied Facets. Springer India, New Delhi, pp. 297-314.

Mishra, P.K., Joshi, P., Suyal, P., Bisht, J.K. and Bhatt, J.C.2014. Potential of phosphate solubilising microorganisms in crop production. In: Bioresources for Sustainable Plant Nutrient Management. Satish Serial Publishing House, New Delhi, India, pp. 201-222.

Mog, B. 2007. Effect of organics and biofertilizers on productivity potential in carrot (Daucus carota L.) Doctoral dissertation, UAS, Dharwad.

Palande, A., Deokar, C. D., Gaykawd, R. T. and Mali, M. D. 2017. Effect of organic manures and biofertilizers on growth and yield of asparagus (Asparagus racemosus). BIOINFOLET-A Quar. J. Life Sci., 14(2):172-174.

Patle, B.J., Wagh, A.P., Umbarkar, P.S. and Bondre, S.V. 2018. Integrated nutrient management studies in bottle gourd. J.Pharmacogn.Phytochem., 7(5):13831385

Pennington, J.A.T. and Fisher, R.A. 2009. Classification of fruits and vegetables. J.Food Compos.Anal., 22(1):23-31.

Mullie, P. and Clarys, P.2011.Association between Cardio- vascular Disease Risk Factor Knowledge and Lifestyle. Food Nutr. Sci., 2(10): 1048-1053.

Ramana,V., Ramakrishna, M., Purushotham, K., Reddy and Balakrishna, K. 2010. Effect of biofertilizers on growth, yield attributes and yield of French bean (Phaseolus vulgaris). Legum. Res., 33(3): 178-183.

Richardson, A.E., Barea, J.M., McNeill, A.M. and Prigent-Combaret, C. 2009. Acquisition of phosphorus and nitrogen in the rhizosphere and plant growth promotion by microorganisms. Plant Soil., 321: 305-339.

Rodrigues, A.C., Bonifacio, A., de Araujo, F.F., Junior, M.A.L. and Figueiredo, M.D.V.B. 2015. Azospirillum sp. as a challenge for agriculture. In: Maheshwari, D.K. (Ed.),Bacterial Metabolites in Sustainable Agroecosystem. Springer International Publishing, Cham, pp. 29-51.

Rodríguez, A., Stella, A., Storni, M., Zulpa, G. and Zaccaro, M. 2006. Effects of cyanobacterial extracellular products and gibberellic acid on salinity tolerance in Oryza sativa L. Saline Syst., 2: 1.

Sahu, D., Priyadarshani, I. and Rath, B.2012. Cyanobacteria as potential biofertilizer. CIB Tech. J. Microbiol., (1):20-26.

Shaheen, A.M., Fatma, M., Rizk, A. and 
Singer, S.M. 2007. Growing onion plants without chemical fertilization. Res. J. Agr. Biol. Sci., 3(2): 95-104.

Shani, K., Sanjay, K., Sutanu, M., and Pandey, V.K. 2017.Effect of inorganic fertilizers and bio-fertilizers on growth, yield and quality of radish (Raphanus sativus L.). J. Environ. Ecol., 35(1): 2528.

Singh, A., Maji, S. and Kumar, S. 2014. Effect of biofertilizers on yield and biomolecules of anti-cancerous vegetable broccoli. IJBSM., 5(2): 262268.

Singh, K. 2001. Response of potato (Solarium tuberosum) to bio-fertilizer and nitrogen under North-Eastern hill conditions. Indian J. Agron., 46(2):375379.

Soetan, K., Olaiya, C. andOyewole, O. 2010. The importance of mineral elements for humans, domestic animals and plants-A review. Afr.J.Food Sci., 4:200-222

Solanki, M.P., Patel, B.N., Tandel, Y.N., and Patel, N. B.2010. Growth, yield and quality of brinjal as affected by use of bio-fertilizers. Asian J. Hortic., 5: 403406.

Thajuddin, N., Subramanian, G. 2005. Cyanobacterial biodiversity and potential applications in biotechnology. Curr. Sci., 89: 47-57.

Thakur, S., Thakur, R., Mehta, D.K. 2018. Effect of biofertilizers on horticultural and yield traits in French bean var. Contender under dry temperate conditions of Kinnaur district of Himachal Pradesh. J. Nat. Appl. Sci., 10(1): 421-424.

Waghmode, H.S., Patil, R.S. andPandure, B.S.2010. Effect of biofertilizer and gibberellic acid on yield contributing character of onion. Int. J. Agric. Sci., 6(2): 392-394.

Wilson, L. 2006. Cyanobacteria: a potential nitrogen source in rice field, vol.6.Texas Rice, pp-9-10

Yadav, B.D., Khandelwal R. and Sharma Y.K. 2004 Use of biofertilizers (Azospirillum) in onion. Haryana $\mathrm{J}$. Hort. Sci., 33(3-4):281-83.

\section{How to cite this article:}

Gurpreet Singh and Anamika Verma. 2020. Role of Microbial Biofertilizers in Vegetable Production- A Review. Int.J.Curr.Microbiol.App.Sci. 9(11): 1620-1629.

doi: https://doi.org/10.20546/ijcmas.2020.911.193 